Bull. Mater. Sci,, Vol. 3, Number 1, February 1981, pp. 9-13. (C) Printed in India.

\title{
Hydrothermal stability of hematite and magnetite
}

\author{
J A K TAREEN and K V KRISHNAMURTHY \\ The Mineralogical Institute, Manasa Gangotri, Mysore 570 006, India
}

MS received 23 July 1980; revised 8 October 1980

\begin{abstract}
Hydrothermal phase stability studies were carried out in the systems (a) $\mathrm{Fe}_{2} \mathrm{O}_{3}-\mathrm{H}_{2} \mathrm{O}$, (b) $\mathrm{Fe}_{2} \mathrm{O}_{3}-\mathrm{H}_{2} \mathrm{O}-\mathrm{CO}_{2}$, (c) $\mathrm{Fe}_{2} \mathrm{O}_{3}-\mathrm{H}_{2} \mathrm{O}-\mathrm{CO}_{2}-\mathrm{H}_{2}$ and (d) $\mathrm{Fe}_{2} \mathrm{O}_{3}-$ $\mathrm{HNO}_{3}$. In the pure system $\mathrm{Fe}_{2} \mathrm{O}_{3}-\mathrm{H}_{2} \mathrm{O}$, only $a-\mathrm{Fe}_{2} \mathrm{O}_{3}$ and $\mathrm{Fe}_{3} \mathrm{O}_{4}$ are the stable solids, with the phase boundary nearly pressure independent around $700^{\circ} \mathrm{C}$. The introduction of $\mathrm{CO}_{2}$ into the system catalyses the stability of a-FeOOH in the system at low temperatures. The presence of $\mathrm{H}_{2}$ in the system produces traces of $\mathrm{Fe}_{3} \mathrm{O}_{4}$ at temperatures as low as $230^{\circ} \mathrm{C}$ and at around $500^{\circ} \mathrm{C}, \mathrm{Fe}_{3} \mathrm{O}_{4}$ is the only stable phase. The stabilisation of $\mathrm{Fe}_{3} \mathrm{O}_{4}$ is suppressed even up to $850^{\circ} \mathrm{C}$, when $\mathrm{NO}_{3}^{-}$ion is present in the fluid phase.
\end{abstract}

Keywords. Hydrothermal stability; $\mathrm{Fe}_{2} \mathrm{O}_{3}$; magnetite; goethite; phase diagram.

\section{Intraduction}

Studies on the hydrothermal stability of hematite and magnetite are important because the reaction of water and iron, particularly in the presence of oxidising or reducing fluids will help in determining the life-time and safe operating conditions for steam boilers, turbines, heat exchangers in nuclear reactors and hydrothermal autoclaves (Kolb et al 1973). Thus phase equilibria studies in the pure $\mathrm{Fe}_{2} \mathrm{O}_{3}-\mathrm{H}_{2} \mathrm{O}$ system, as well as the stability of hematite and magnetite in the presence of different oxidising and reducing agents are important for providing information on aqueous corrosion of steel autoclaves, turbines, etc. (Ikornikova 1960). It is generally agreed (Ikornikova 1960; Tomlinson 1973; Mann 1973) that with pure water (under high temperatures and pressures) passivation of steel takes place due to the formation of dense layer of magnetite. The present authors have investigated the stability of hematite and magnetite in the following systems : (a) $\mathrm{Fe}_{2} \mathrm{O}_{3}-\mathrm{H}_{2} \mathrm{O}$, (b) $\mathrm{Fe}_{2} \mathrm{O}_{3}-\mathrm{H}_{2} \mathrm{O}-\mathrm{CO}_{2}$, (c) $\mathrm{Fe}_{2} \mathrm{O}_{3}-\mathrm{H}_{2} \mathrm{O}-\mathrm{CO}$, (d) $\mathrm{Fe}_{2} \mathrm{O}_{3}-\mathrm{H}_{2} \mathrm{O}-\mathrm{CO}_{2}-$ $\mathrm{H}_{2}$ and (e) $\mathrm{Fe}_{2} \mathrm{O}_{3}-\mathrm{HNO}_{3}$. The results of $\mathrm{Fe}_{2} \mathrm{O}_{3}-\mathrm{H}_{2} \mathrm{O}-\mathrm{CO}$ system and part of the $\mathrm{Fe}_{2} \mathrm{O}_{3}-\mathrm{H}_{2} \mathrm{O}$ system were reported by the authors earlier (Viswanathiah et al 1980). In the $\mathrm{Fe}_{2} \mathrm{O}_{3}-\mathrm{H}_{2} \mathrm{O}-\mathrm{CO}$ system $\left(\mathrm{Fe}_{2} \mathrm{O}_{3}-\mathrm{HCOOH}\right)$ the magnetite was reported to crystallise at temperature as low as $200^{\circ} \mathrm{C}$. With further studies in the $\mathrm{Fe}_{2} \mathrm{O}_{3}-\mathrm{H}_{2} \mathrm{O}$ system the phase diagram has been constructed, which is presented in the present paper, along with the discussion on the other systems mentioned above. 


\section{Experimental}

Iron hydroxide gel (amorphous to $\mathrm{x}$-rays) prepared by hydrolysing ferric chloride solution with aqueous ammonia was used as the starting material. The dried gel (at $110^{\circ} \mathrm{C}$ ) on analysis gave $21 \%$ of $\mathrm{H}_{2} \mathrm{O}$ and $79 \%$ of $\mathrm{Fe}_{2} \mathrm{O}_{3}$. The following materials were used to introduce $\mathrm{CO}_{2}, \mathrm{H}_{2}$ and $\mathrm{NO}_{3}$ in the fluid phase of the different systems.

(a) $\mathrm{Fe}_{2} \mathrm{O}_{3}-\mathrm{H}_{2} \mathrm{O}-\mathrm{CO}_{2}$ system : Ferric hydroxide gel $(70 \mathrm{mg})$ mixed with freshly prepared silver oxalate $(100 \mathrm{mg})$, along with $3-4$ drops of distilled water, has been taken as the starting material. Silver oxalate decomposes at about $150^{\circ} \mathrm{C}$, to give silver and carbon dioxide.

(b) $\mathrm{Fe}_{2} \mathrm{O}_{3}-\mathrm{H}_{2} \mathrm{O}-\mathrm{CO}_{2}-\mathrm{H}_{2}$ system : Iron hydroxide gel (80-100 mg) oxalic acid dihydrate $\left(\mathrm{H}_{2} \mathrm{C}_{2} \mathrm{O}_{4} 2 \mathrm{H}_{2} \mathrm{O}\right)(20-30 \mathrm{mg})$ have been used as the source $\mathrm{CO}_{2}$ and $\mathrm{H}_{2}$ along with $\mathrm{H}_{2} \mathrm{O}$. The expected decomposition is $\mathrm{C}_{2} \mathrm{H}_{2} \mathrm{O}_{4} 2 \mathrm{H}_{2} \mathrm{O} \stackrel{200^{\circ} \mathrm{C}}{\longrightarrow} \mathrm{CO}_{2}+$ $\mathrm{CO}+3 \mathrm{H}_{2} \mathrm{O} \underset{\text { in steam }}{\stackrel{200^{\circ} \mathrm{C}}{\rightarrow}} 2 \mathrm{CO}_{2}+2 \mathrm{H}_{2} \mathrm{O}+\mathrm{H}_{2}$ thus producing a partial pressure of $\mathrm{CO}_{2}\left(\mathrm{X}_{\mathrm{CO}_{2}}\right)$ value of 0.5 , in the fluid phase.

(c) $\mathrm{Fe}_{2} \mathrm{O}_{3}-\mathrm{HNO}_{3}$ system : Concentrated nitric acid (4-5 drops) is taken along with about $100 \mathrm{mg}$ of the iron hydroxide gel.

The charges in all the above systems and also for the pure $\mathrm{Fe}_{2} \mathrm{O}_{3}-\mathrm{H}_{2} \mathrm{O}$ systems were taken in platinum ampoules (L : $5 \mathrm{~cm}$, I.D. : $5 \mathrm{~mm}$, O.D. : $5.2 \mathrm{~mm}$ ) and sealed by arc welding. Leaks in the ampoule were checked through extended heating as well as by recording the weight before and after the experiment. The experiments were done using test-tube-type stellite cold seal reactors with Tempress unit HR-IB-4. The vessels after the run were quenched with air blast before venting out the pressure. The $\mathrm{Fe}_{2} \mathrm{O}_{3}-\mathrm{H}_{2} \mathrm{O}$ system was studied in the temperature range of $100-850^{\circ} \mathrm{C}$ in the pressure range of $60-1300 \mathrm{~atm}$. The other systems were studied at low pressures of 200-500 atm. and at selected ranges of temperatures. All the experiments were for a duration $90-100 \mathrm{hr}$. The products were identified with the $\mathrm{x}$-ray powder photographs $\left(114 \mathrm{~mm} \mathrm{CZ}\right.$ camera, $\mathrm{COK}_{a^{-}}$ radiation.)

\section{Results and discussion}

\section{1. $\mathrm{Fe}_{2} \mathrm{O}_{3}-\mathrm{H}_{2} \mathrm{O}$ system}

Although a limited number of experiments conducted in this system were reported earlier (Viswanathiah et al 1980), further studies on this system with over twenty runs, enabled the authors to construct a phase diagram (figure 1). The results of the new experiments along with the reported ones are tabulated in table 1. It is interesting to note that the $a-\mathrm{Fe}_{2} \mathrm{O}_{3}$ is stable up to temperatures as low as $100^{\circ} \mathrm{C}$ and the boundary between $a-\mathrm{Fe}_{2} \mathrm{O}_{3}$ and $\mathrm{Fe}_{3} \mathrm{O}_{4}$ lies around $700^{\circ} \mathrm{C}$. The goethite phase $(a-\mathrm{FeOOH})$ which is reported to be stable by Schmalz (1956) upto $130^{\circ} \mathrm{C}$ is not detected in the present expriment. The $a-\mathrm{Fe}_{2} \mathrm{O}_{3}$ should thermodynamically be in equilibrium with $\mathrm{H}_{2} \mathrm{O}$ up to $1050^{\circ} \mathrm{C}$ (Wagman et al 1945; Laudise 1962; Norton 1955; Eugster 1959). But in the present case it is stable only up to $700^{\circ} \mathrm{C}$ and beyond this $\mathrm{Fe}_{3} \mathrm{O}_{4}$ is the stable phase. The stabilization of $\mathrm{Fe}_{3} \mathrm{O}_{4}$ at lower temperatures was attributed by Laudise et al (1961) to slow diffusion of hydrogen. 


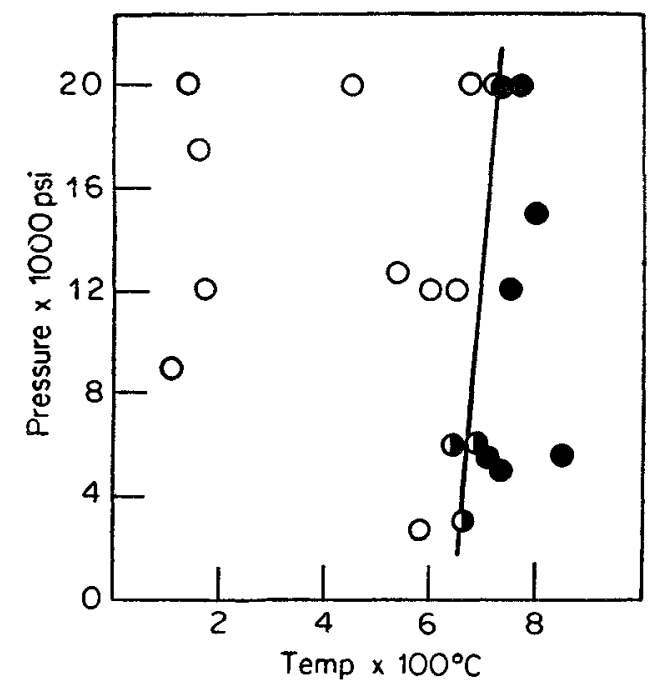

Figure 1. Phase diagram for $\mathrm{Fe}_{2} \mathrm{O}-\mathrm{H}_{2} \mathrm{O}$ system. $\mathrm{O}: \alpha-\mathrm{Fe}_{2} \mathrm{O}_{3}, \bullet: \mathrm{Fe}_{3} \mathrm{O}_{4}$.

\section{2. $\mathrm{Fe}_{2} \mathrm{O}_{3}-\mathrm{H}_{2} \mathrm{O}-\mathrm{CO}_{2}$ system}

The experimental conditions and results in this system are given in table 1. Only three experiments have been carried out to check if $\mathrm{CO}_{2}$ in the system would catalyse the formation of goethite $(a-\mathrm{FeOOH})$ or lepidocrocite $(\beta-\mathrm{FeOOH})$ since these phases are not detected in pure $\mathrm{Fe}_{2} \mathrm{O}_{3}-\mathrm{H}_{2} \mathrm{O}$ system. Experiments from $100^{\circ} \mathrm{C}$ to $500^{\circ} \mathrm{C}$ showed that goethite does stabilize at $100^{\circ} \mathrm{C}$ but above $130^{\circ} \mathrm{C}, a-\mathrm{Fe}_{2} \mathrm{O}_{3}$ is the stable phase. The upper stability limit of $a-\mathrm{Fe}_{2} \mathrm{O}_{3}$ is not determined in this system.

\section{3. $\mathrm{Fe}_{2} \mathrm{O}_{3}-\mathrm{H}_{2} \mathrm{O}-\mathrm{CO}_{2}-\mathrm{H}_{2}$ system}

Only three runs have been carried out in this system to check the stability of hematite and magnetite. Oxalic acid dihydrate is the source of $\mathrm{H}_{2} \mathrm{O}, \mathrm{CO}_{2}$ as well as $\mathrm{H}_{2}$. It is interesting to note that the hydrogen liberated in the system does not quickly diffuse out through the platinum ampoule and instead it reduces $a-\mathrm{Fe}_{2} \mathrm{O}_{3}$ to $\mathrm{Fe}_{3} \mathrm{O}_{4}$. In fact at $550^{\circ} \mathrm{C}$ and above magnetite is the only stable phase. Although the duration of the run in the present case is only of $60 \mathrm{hr}$, it is not certain whether the extended runs for several days would still retain enough $\mathrm{H}_{2}$ in the ampoule and $\mathrm{Fe}_{3} \mathrm{O}_{4}$ would get stabilised.

\section{4. $\mathrm{Fe}_{2} \mathrm{O}_{3}-\mathrm{HNO}_{3}$ system}

This system was investigated to understand the stability of iron oxide in an oxidizing atmosphere in the presence of $\mathrm{NO}_{3}$ ions in the fluid phase. As expected, $\mathrm{Fe}_{3} \mathrm{O}_{4}$ formation is suppressed and even at $850^{\circ} \mathrm{C} a-\mathrm{Fe}_{2} \mathrm{O}_{3}$ is the only stable phase. 


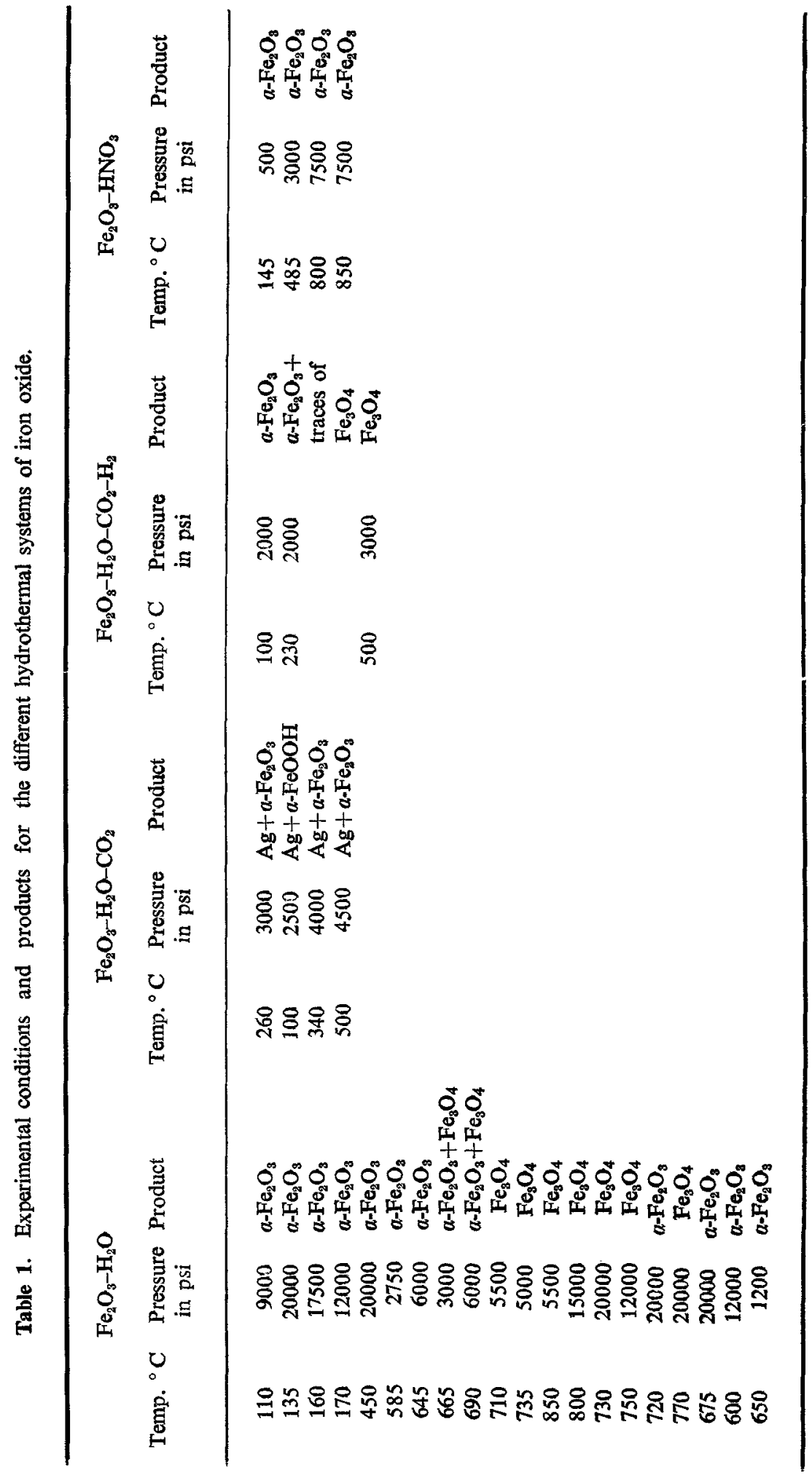




\section{Conclusion}

The authors hope that the present results have given a fairly good picture of the hydrothermal chemistry of iron oxides in the presence of different oxidising and reducing ions in the fluid phase and its implications on the boilers, turbine and other steel autoclaves using such fluids are obvious. The fact that goethite is not stable in pure $\mathrm{Fe}_{2} \mathrm{O}_{3}-\mathrm{H}_{2} \mathrm{O}$ system and that the same appears in the system $\mathrm{Fe}_{2} \mathrm{O}_{3} \mathrm{H}_{2} \mathrm{O}-\mathrm{CO}_{2}$ indicate that the formation of an oxyhydroxide phase requires a catalyser in the system and here $\mathrm{CO}_{2}$ has served to stabilise goethite.

\section{References}

Eugster H P 1959 Researches in geochemistry ed. P H A Belson (New York: Wiley) p. 397 Ikornikova N Yu 1960 Dokl. Akad. Nauk. (USSR) 130610

Kolb E D, Caporaso A J and Laudise R A 1973 J. Cryst. Growth 19242

Laudise R A, Craket J H and Ballman A A 1961 J. Phys. Chem. 65359

Laudise R A 1962 In Progress in inorganic chemistry ed. F A Cotton (New York: Interscience) Vol. $11120-24$

Mann G M 1973 High pressure aqueous electrochemistry Proc. Int. Conf. Univ. of Surrey, England (Surrey: Surrey Univ. Publ.)

Norton F J 1955 General Electric Report 55-R1-1248

Schmalz R 1959 J. Geophys. Res. 64575

Tomlinson M 1973 High temperature-high pressure aqueous electrochemistry Proc. Int. Conf. Univ. of Surrey, England

Viswanathiah M N, Tareen J A K and Krishnamurthy K A 1980 J. Cryst. Growth 49189

Wagman D D, Kilpatrick J E, Taylor W J, Pitzer K S and Rossini F D 1945 J. Res. Natl. Bur. Std. 34143 